\title{
Meningkatkan Sumber Daya Guru Untuk Menjamin Mutu Pendidikan Melalui Supervisi Pendidikan
}

\author{
Wira Yulianti
}

17329140

E-mail wirayulianty47985@.com

\begin{abstract}
Abstrak
guru merupakan salah satu unsur yang terpenting dalam pendidikan karena baik buruknya kualitas pendidikan sangat ditentukan oleh standar kualitas guru tersebut. dalam neningkatkan kualitas sumber daya guru dalam pendidikan, guru sutu komponen sumber daya manusia yang harus dibina dan dikembangkan terus menerus untuk mengembangkan potensi yang dimiliki guru maka harus dibantu oleh sesama guru untuk saling bekerja sama dalam pendidikan. sehingga menghasilkan guru professional yamg memiliki tugas untuk mendidik, melatih, mengajar, membimbing, menilai dan mengevaluasi peserta didik dapat mendukung dalam pencapaian tujuan untuk menjadikan guru professional. karena pengaruh perubahan yang sangat cepat mendorong guru-guru untuk terus belajar menyesuaikan diri dengan perkembangan ilmu pengetahuan dan teknologi serta mobilitas dengan masyarakat. supervisi pendidikan memiliki peranan yang penting dalam meningkatkan sumber daya guru yang menghasikan guru yang professional.
\end{abstract}

Kata kunci: supervisi pendidikan, meningkatkan sumber daya guru 


\section{A. Latar belakang}

Guru adalah seseorang yang mengajarkan kita dari yang tidak kita ketahui sampai kita mengetahuinya. Tanpa adanya guru kita tidak bisa melakukan proses pembelajaran,jadi guru merupakan salah satu unsur terpenting dalam pendidikan karena baik buruknya kualitas pendidikan sangat ditentukan oleh standar kualitas guru tersebut. oleh karena itu, guru perlu meningkatkan kompetensinya seperti tercantum dalam undang-undang nomor 14 tahun 2005 tentang guru dan dosen pada pasal 2 ayat 1 disebutkan bahwa, guru mempunyai kedudukan sebagai tenaga professional pada jenjang pendidikan dasar, pendidikan menengah, dan pendidikan anak usia dini pada jalur pendidikan formal yang diangkat sesuai dengan peraturan perundang -undangan. Sedangkan pada pasal ayat 2 disebutkan bahwa pengakuan kedudukan guru sebagai tenaga professional sebagaimana dimaksudkan pada ayat 1 dibuktikan dengan sertifikat pendidik.

Profesi adalah pekerjaan atau kegiatan yang dilakukan oleh seseorang dan menjadi sumber penghasilan kehidupan yang memerlukan, kemahiran, atau kecakapaan yang memenuhi standar mutu atau norma tertentu serta memerlukan pendidikan profesi. Jadi guru yang professional adalah pendidik yang tugasnya meliputi mendidik, mengajar, membimbing, mengarahkan, melatih, menilai, dan mengevaluasi peserta didik di sekolah tugas itu menjadi sumber penghasilan kehidupan yang memerlukan keahlian, kemahiran, atau kecakpan, yang memerlukan standar mutu atau norma tertentu serta memerlukan pendidikn profesi.

Dalam meningkatkan kualitas sumber daya pendidikan, guru merupakan komponen sumber daya manusia yang harus dibina dan dikembangkan terus menerus. Guru adalah tugasnya yang terkait dengan upaya mencerdaskan kehidupan bangsa dalam semua aspeknya baik spiritual, emosional, fisikal maupun aspek lainnya (Suparlan, 2005) Menurut pendapat saya guru memang harus dibina agar menjadi guru yang professional sehingga potensi yang dimiliki guru dapat berkembang. Untuk mengembangkan potensi yang dimiliki guru maka ia harus dibantu oleh sesama guru. Karena pengaruh perubahan yang yang sangat cepat mendorong guru- guru untuk terus menerus belajar menyesuaikan diri dengan perkembangan ilmu pengetahuan dan teknologi serta mobilitas dengan masyarakat. 
Mutu pendidikan sering diartikan sebagai karakteristik jasa pendidikan yang sesuai dengan kriteria tertentu untuk memenuhi pserta didik, orang tua serta pihak -pihak yang berkepentingan lainnya.untuk berjalannya mutu pendidikan seperti yang diinginkan oleh orang banyak maka harus mengikuti prosesnya dan menjalankan komponen pendukungnya.tenaga pendidik (guru) merupakan elemen kunci dalam sistem pendidikan khususnya di sekolah.(depertemen pendidikan nasional, 2008) Hal ini disebabkan karena guru adalah titik sentral dalam pembaharuan dan peningkatan mutu pendidikan, dengan demikian syarat untuk terwujudnya pendidikan yang bermutu adalah apabila pelaksananaya dilakukan oleh guru atau pendidik yang keprefesionalnya dapat diandalkan.

Supervisi pendidikan berkembang seiring dengan perkembangan ilmu pengetahuan, teknologi, serta sosial ekonomi dan budaya masyarakat . supervisi lebih dominasi oleh supervisor dam bentuk kolaborasi antara supervisor dan guru. Supervisor dan guru bekerja sama dalam meningkatkan kualitas pembelajaran, dan juga untuk membantu guru agar selalu meningkatkan kompetensinya.(Sabandi, 2013)

\section{B.Rumusan Masalah}

Untuk memudahkan dalam penyusunan artikel ini , penulis membuat suatu rumusan masalah yang akan diangkat menjadi topik pembahasan. Yaitu:(1) bagaimana cara meningkatkan sumber daya guru yang professional,(2) mengapa kurangnya guru professional dalam mengajar peserta didik sehingga banyak yang tidak mengerti dengan pelajaran yang dijelaskan oleh guru.

\section{C.tujuan}

Berdasarkan rumusan masalah diatas, maka tujuan penulisan yang ingin penulis capai adalah : (1) agar dapat mengetahui dan memahami cara meningkatkan sumber daya guru yang professional, (2) agar dapat mengetahui dan memahami kurangnya guru yang professional dalam mengajar peserta didik sehingga banyak yang tidak mengerti dengan pelajran yang dijelaskan oleh guru.

\section{Pembahasan}


Seorang guru yang professional harus mampu mendidik peserta didiknya untuk menjadi manusia yang berguna untuk Negara dan agama. Begitu banyak masalah yang membuat guru tidak professional dalam bekerja seperti masalah kualitas guru, jumlah guru yang masih kurang,masalah kesejahteraan guru dan masalah distribusi guru. Jadi masalahnya disini adalah banyak kita temukan guru yang tidak professional dalam proses pembelajaran ketika mengajar, guru hanya duduk di dalam kelas dan memberi tugas tanpa menerangkan pelajaran dan ada juga guru yang tidak masuk kelas tanpa memberi alasan yang jelas . seharusnya guru itu mendidik, menilai dan membimbing peserta didik agar memahami apa yang dipelajarinya Dan adapun karena kualifikasi dan latar belakng pendidikan tidak sesuai dengan bidang tugas, tidak memiliki kompetensi yang diperlukan sesuai bidang tugas, penghasilan tidak ditentukan sesuai dengan prestasi kerja, dan kurangnya kesempatan untuk mengembangkan profesi secara berkelanjutan.

Jadi yang harus dilakukan dalam mengatasi guru yang kurang profesioanal dalam mengajar yaitu dengan memahami standar tuntutan profesi yang ada, mencapai kualifikasi dan kompetensi yang dipersyaratkan, membangaun kesejawatanyang baik dan luas termasuk lewat organisasi profesi, mengembangkan etos kerja atau budaya kerja yang mengutamakan pelayanan bermutu tinggi.dalam meningkatkan sumber daya guru dapat dilakukan dengan melakukan pelatihan untuk meningkatkan kompetensi guru karena dengan kemajuan zaman teknologi semakin canggih sehingga guru harus mengerti dengan IPTEK, dan meningkatkan sarana belajar mengajar sehingga guru nayman berada di dalam kelas ketika mengajar.

Karakteristik sumber daya yang berkualitas yang memiliki kemampuan, nilai, dan sikap yang perlu dikuasai dan dimiliki manusia terdidik Indonesia meliputi(Soedijarto, 2008) :

1. memiliki kemampuan, nilai dan sikap yang memungkinkannya berpartisipasi secara aktif, cerdas dalam proses politik;

2. memiliki kemampuan, etos kerja dan disiplin kerja yang memungkinkannya aktif dan produktif berpartisipasi dalam berbagai kegiatan ekonomi;

3. memiliki kemampuan dan sikap ilmiah untuk dapat mengembangkan ilmu pengetahuan dan teknologi melalui kemampuan penelitian dan pengembangan;

4. memiliki kepribadian yang mantap, berkarakter dan bermoral, serta berakhlak mulia. 
Dalam meningkatkan sumber daya guru khususya disini pada pendidik harus memiliki kemampuan dan keahlian, disiplin, dan bertanggung jawab sehingga menjadi guru yang professional.

Tujuan profesionalisme guru untuk meningkatkan mutu pendidikan menurut (Surya, 2008) bahwa guru mempunyai peranan penting dalam peningkatan mutu pendidikan, karena:

1.guru dapat memberikan jaminan perlindungan kepada kesejahteraan masyarakat umum.

2. guru merupakan suatu cara untuk memperbaiki citra profesi pendidikan yang selama ini dianggap oleh sebahagian masyarakat rendah.

3. guru memungkinkan perbaikan dan pengembangan diri yang memberikan kemungkinan guru dapat memberikan pelayanan sebaik mungkin dan memaksimalkan kompetensinya.

tujuan dari guru professional memiliki peran yang sangat besar dalam upaya untuk meningkatkan mutu pendidikan karena guru merupakan komponen penting dalam proses pembelajaran . karena dengan adnya guru yang professional maka akan meningkatkan mutu pendidikan semakin profesionala seorang guru, maka semakin dapat memperbaiki proses pembelajaran, dan semakin meningkat kualitas pencapaian tujuan pembelajaran. 


\section{Penutup}

\section{a..kesimpulan}

berdasarkan masalah diatas dapat disimpulkan bahwa Guru adalah pendidik professional dengan tugas utama mengajar, mendidik, membimbing, mengarahkan, melatih, menilai, dan mengevaluasi peserta didik. Karena seorang guru memiliki peran yang sangat penting dalam proses pembelajran tanpa guru pelajaran tidak akan dapat berjalan dengan baik .dengan demikian untuk menjadi guru yang professional dapat meningkatkan mutu pendidikan.

Jadi yang harus dilakukan dalam mengatasi guru yang kurang profesioanal dalam mengajar yaitu dengan memahami standar tuntutan profesi yang ada, mencapai kualifikasi dan kompetensi yang dipersyaratkan, membangaun kesejawatanyang baik dan luas termasuk lewat organisasi profesi, mengembangkan etos kerja atau budaya kerja yang mengutamakan pelayanan bermutu tinggi.dalam meningkatkan sumber daya guru dapat dilakukan dengan melakukan pelatihan untuk meningkatkan kompetensi guru karena dengan kemajuan zaman teknologi semakin canggih sehingga guru harus mengerti dengan IPTEK, dan meningkatkan sarana belajar mengajar sehingga guru nayman berada di dalam kelas ketika mengajar.

b. saran

Dalam penulisan artikel penulis merasa bahwa artikel ini masih banyak kekurangan. Untuk itu, penulis sangat mengharapkan kritik dan saran dari pembaca agar dapat membuat makalah ini lebih baik dan mendekati sempurna, sehingga dapat membantu para pendidik dalam meningkatkan profesionalnya sebagai seorang guru. 


\section{DAFTAR PUSTAKA}

depertemen pendidikan nasional. (2008). panduan pengembangan bahan ajar. Jakarta: depdiknas.

Sabandi, A. (2013). SUPERVISI PENDIDIKAN UNTUK PENGEMBANGAN PROFESIONALITAS GURU BERKELANJUTAN. Jurnal Ilmiah Ilmu Pendidikan, XIII(2), 1-9.

Soedijarto. (2008). Landasan dan Arah Pendidikan Nasional kita. Jakarta: penerbit kompas.

Suparlan. (2005). menjadi guru efektif. yogyakarta: hikayat.

Surya. (2008). Kapita Selrkta Pendidikan SD. Jakarta: Universitas Terbuka. 